\title{
Teaching NeuroImages: Vertebrobasilar dolichoectasia with dissection manifested as infarct and subarachnoid hemorrhage
}

Xinmiao Zhang, MD, * Jing Jing, MD, PhD, * Kehui Dong, MD, Yilong Wang, MD, PhD, and Yongjun Wang, MD Neurology ${ }^{\circledR}$ 2018;90:e990-e991. doi:10.1212/WNL.0000000000005119

\section{Correspondence}

Dr. Yongjun Wang yongjunwang1962@gmail. com or Dr. Yilong Wang yilong528@gmail.com

Figure Radiologic imaging features of the patient
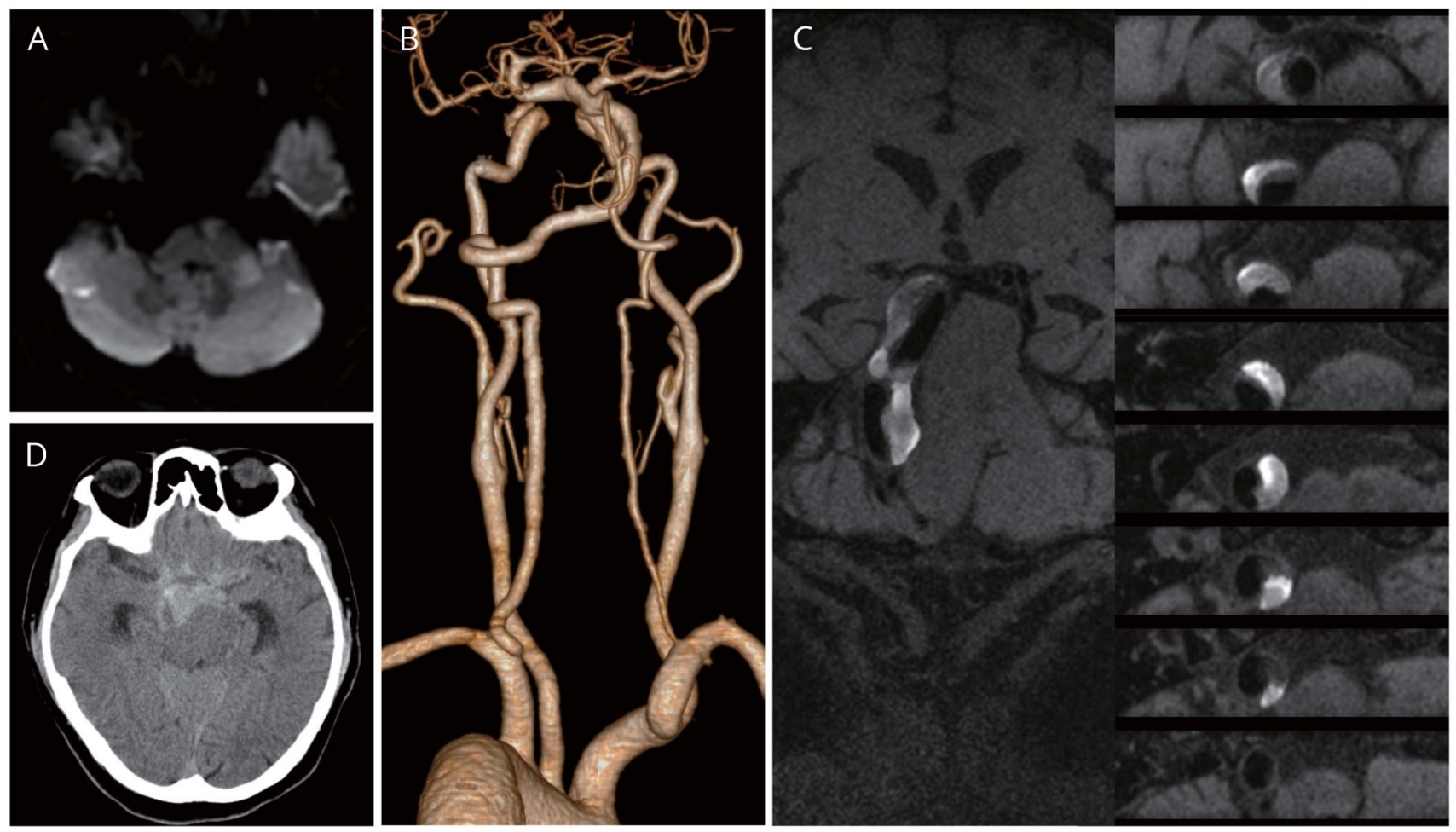

(A) Diffusion-weighted imaging shows acute infarctions of cerebellar hemispheres and pons. (B) CT angiography shows vertebrobasilar dolichoectasia. (C) High-resolution MRI (T1-CUBE) shows a crescentic high signal of the basilar artery and left vertebral artery, indicating intramural hematoma of artery dissection. (D) CT shows subarachnoid hemorrhage in the suprasellar cistern.

A 60-year-old man presented with vertigo, dysarthria, and left weakness. MRI and CT angiography showed multifocal infarctions and vertebrobasilar dolichoectasia (VBD) (figure, A and $\mathrm{B}$ ). High-resolution MRI showed dissection of basilar artery and left vertebral artery (figure, C). He had subarachnoid hemorrhage (SAH) on the 10th day (figure, D) and died on the 30th day. VBD with dissection can manifest as sequential infarct and SAH, which predicts poor prognosis. ${ }^{1}$ High-resolution MRI is a useful tool to detect dissection in VBD. No consensus has been reached on treatment of VBD; antiplatelet agents, anticoagulants, surgical, and endovascular treatment are all treatment options. ${ }^{2}$

\section{MORE ONLINE}

\section{$\rightarrow$ Teaching slides:}

links.lww.com/WNL/A234

*These authors contributed equally to this work.

From the Department of Neurology, Beijing Tiantan Hospital, Capital Medical University; China National Clinical Research Center for Neurological Diseases; Center of Stroke, Beijing Institute for Brain Disorders; and Beijing Key Laboratory of Translational Medicine for Cerebrovascular Disease, China.

Go to Neurology.org/N for full disclosures. Funding information and disclosures deemed relevant by the authors, if any, are provided at the end of the article. 


\section{Author contributions}

Xinmiao Zhang: acquisition of images and data, drafting of the manuscript. Jing Jing: analysis and interpretation of data, drafting of the manuscript. Kehui Dong: analysis and interpretation of data. Yilong Wang: study concept and design, revising the manuscript. Yongjun Wang: study supervision, revising the manuscript for content.

\section{Study funding}

No targeted funding reported.

\section{Disclosure}

The authors report no disclosures relevant to the manuscript. Go to Neurology.org/N for full disclosures.

\section{References}

1. Matsukawa H, Shinoda M, Fujii M, Uemura A, Takahashi O, Niimi Y. Basilar dolichoectasia and the spontaneous intradural vertebral artery dissection. Brain Inj 2016; 30:90-94.

2. Wolters FJ, Rinkel GJ, Vergouwen MD. Clinical course and treatment of vertebrobasilar dolichoectasia: a systematic review of the literature. Neurol Res 2013;35: 131-137. 


\section{Neurology}

\section{Teaching NeuroImages: Vertebrobasilar dolichoectasia with dissection manifested as infarct and subarachnoid hemorrhage \\ Xinmiao Zhang, Jing Jing, Kehui Dong, et al. \\ Neurology 2018;90;e990-e991 \\ DOI 10.1212/WNL.0000000000005119}

\section{This information is current as of March 12, 2018}

\section{Updated Information \&} Services

References

Subspecialty Collections

Permissions \& Licensing

Reprints including high resolution figures, can be found at: http://n.neurology.org/content/90/11/e990.full

This article cites 2 articles, 0 of which you can access for free at: http://n.neurology.org/content/90/11/e990.full\#ref-list-1

This article, along with others on similar topics, appears in the following collection(s):

\section{Infarction}

http://n.neurology.org/cgi/collection/infarction

MRI

http://n.neurology.org/cgi/collection/mri

Subarachnoid hemorrhage

http://n.neurology.org/cgi/collection/subarachnoid_hemorrhage

Information about reproducing this article in parts (figures,tables) or in its entirety can be found online at:

http://www.neurology.org/about/about_the_journal\#permissions

Information about ordering reprints can be found online:

http://n.neurology.org/subscribers/advertise

Neurology ${ }^{\circledR}$ is the official journal of the American Academy of Neurology. Published continuously since 1951, it is now a weekly with 48 issues per year. Copyright @ 2018 American Academy of Neurology. All rights reserved. Print ISSN: 0028-3878. Online ISSN: 1526-632X.

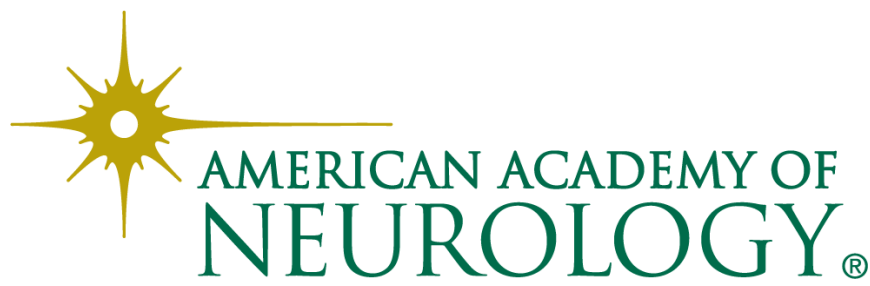

